\title{
NILAI-NILAI COWORKING SPACE DALAM MENDUKUNG KONSEP KOTA KREATIF (STUDI KASUS: DAERAH ISTIMEWA YOGYAKARTA)
}

\author{
Ni’mah Mahnunah ${ }^{1)}$, Citra Desy Aisyah Alkis ${ }^{2)}$ \\ ${ }^{1,2}$ Fakultas Sains dan Teknologi, Universitas Amikom Yogyakarta \\ Email : nimahmahnunah@amikom.ac.id
}

\begin{abstract}
Abstrak
Globalisasi dan perkembangan teknologi informasi dan komunikasi membawa perekonomian dunia saat ini telah memasuki era ekonomi kreatif, yang memberikan implikasi pada pengembangan konsep kota kreatif dalam perencanaan dan pengembangan kota. Daerah Istimewa Yogyakarta sebagai kota yang telah dikenal menjadi pusat budaya dan pendidikan didalamnya memiliki sumber daya utama kota kreatif yaitu orang-orang kreatif. Penerapan konsep kota kreatif yang dapat dilihat dari aspek fisik yaitu keberadaan ruang-ruang kreatif yang salah satunya berupa coworking space. Coworking space sebagai wadah dalam menumbuhkan kembangkan kreativitas dan inovasi orang-orang kreatif. Penelitian ini bertujuan untuk mengkaji nilai - nilai coworking space dalam mendukung konsep kota kreatif dengan menggunakan studi kasus di Daerah Istimewa Yogyakarta. Penelitian ini menggunakan pendekatan kualitatif dengan metode analisis deskriptif kualitatif menggunakan studi kasus. Hasil penelitian menunjukkan bahwa nilainilai coworking space di Daerah Istimewa Yogyakarta sebagai lingkungan kerja di sektor kreatif mampu mendorong munculnya komunitas, kolaborasi, komunikasi, dan kreativitas dapat berkontribusi dalam menghasilkan inovasi dan penciptaan peluang nilai ekonomi. Keberadaan coworking space di kota ini juga memiliki peranan yang signifikan dalam hal menghasilkan orangorang kreatif atau pekerja kreatif (creative class) sebagai sumber daya utama dalam pengembangan kota kreatif.. Hasil penelitian ini merupakan bagian dari penerapan konsep kota kreatif dari salah satu aspek lingkungan kreatif berupa coworking space, penelitian selanjutnya dapat mengkaji peran dan pola sebaran coworking space di konteks kota kreatif.
\end{abstract}

Kata Kunci: Coworking space, Kota kreatif, Nilai-nilai,

\begin{abstract}
Globalization and the development of information and communication technology have brought the world economy into the creative economy era, which has implications for the development of the concept of creative cities in urban planning and development. Yogyakarta is a city that has been known to be a center of culture and education has the main resource of creative cities, namely creative people. The application of the concept of a creative city that can be seen from the physical aspect is the existence of creative spaces, one of which is a coworking space. Coworking space is a space for fostering creativity and innovation of creative people. This study aims to examine the values of coworking space in supporting the concept of a creative city using a case study in the Special Region of Yogyakarta. This research uses a qualitative approach with a qualitative descriptive analysis method using a case study. The result shows that the values of coworking space in the Special Region of Yogyakarta as a work environment in the creative sector can encourage the emergence of community, collaboration, communication, and creativity can contribute to generating innovation and creating economic value opportunities. The existence of coworking spaces in this city also has a significant role in producing creative people or creative workers (creative class) as the main resource in the development of a creative city. The result of this study
\end{abstract}


is part of the application of the concept of a creative city from one of the aspects of a creative environment in the form of a coworking space, the further studies can be examined of the role and distribution patterns of coworking space in the creative city context.

Keywords: coworking space, creative city, values,

\section{PENDAhULUAN}

Teknologi informasi dan komunikasi yang semakin berkembang, serta fenomena globalisasi membawa status perekonomian dunia saat ini telah memasuki era ekonomi kreatif yang menekankan pada kreativitas dan informasi yang mengandalkan ide dan pengetahuan yang merupakan faktor utama dalam era ini. Perkembangan sektor ekonomi kreatif ini juga terjadi di Indonesia yang dapat dilihat dari meningkatnya kontribusi sektor ekonomi kreatif terhadap Pendapatan Domestik Bruto mengalami kenaikan dari 7,38\% pada tahun 2015 menjadi 7,44 pada tahun 2017 (https://finance.detik.com/ diakses pada Juli, 2020). Era ekonomi kreatif ini juga membawa pengaruh pada perkembangan kawasan perkotaan yang merupakan kawasan pemusatan penduduk yaitu pemanfaatan kreativitas dalam menghasilkan produk yang memiliki nilai secara ekonomi. Perkembangan ekonomi kreatif ini juga sejalan dengan beberapa kota besar di Indonesia mulai menerapkan konsep kota kreatif untuk memfasilitasi sektor ekonomi kreatif serta menciptakan alternatif dalam menciptakan alternatif solusi atas permasalahan perkotaan. Dimulai tahun 2017, Pemerintah Indonesia melalui Badan Ekonomi Kreatif telah melakukan penilaian 10 kota kreatif yang salah satunya adalah dilakukan di Yogyakarta. Yogyakarta merupakan daerah yang minim akan sumber daya alam, sehingga salah satu fokus sehingga fokus pengembangannya mengarah pada sektor-sektor ekonomi yang bukan berbasis pada penggunaan sumber daya alam, misalnya sektor jasa dan sektor ekonomi kreatif. Hal ini juga didukung dalam pernyataan pers oleh Presiden Joko Widodo pada tanggal 20 April 2017 yang menyatakan bahwa masa mendatang, sektor industri jasa dan kreatif akan menghasilkan kemajuan bagi perekonomian daerah karena sektor ini lebih mengandalkan pada inovasi teknologi (Bekraf, 2017).

Yogyakarta sebagai kota yang telah dikenal sebagai pusat budaya dan pendidikan mencerminkan di dalamnya memiliki sumber daya utama kota kreatif yaitu orang-orang kreatif menjadikan kota ini sebagai area perkembangan industri kreatif (Bekraf, 2017). Menurut data dari BPS tahun 2015, jumlah total mahasiswa keseluruhan perguruan tinggi di Yogyakarta yaitu 184.328 orang. Dengan banyaknya jumlah mahasiswa, Yogyakarta juga sebagai area tujuan startup dan freelancer. Penelitian yang telah dilakukan oleh Jogja Digital Valley pada tahun 2014 disebutkan bahwa Yogyakarta sebagai area untuk mengembangkan bisnis berbasis digital kreatif dengan alasan bahwa kota ini memiliki karakter dan fasilitas pendukungnya untuk bisnis ini. Kemudian Yogyakarta juga mampu mencerminkan perkembangan kota kreatif yang salah satunya ditandai dengan keberadaan ruang kreatif berupa coworking space atau ruang kerja bersama sebagai wadah menumbuhkan kembangkan kreativitas dan inovasi.

Sebagai salah satu bentuk creative hub, istilah coworking space telah dikenalkan oleh Pusat Kebudayaan Inggris yang mengidentifikasi ruang virtual atau ruang fisik yang dapat dijadikan tempat untuk mempertemukan orang-orang kreatif (British Council, 2017). British Council mempopulerkan coworking space sebagai bentuk dari pusat kreatif yang merupakan tempat, baik fisik atau virtual yang dapat menyatukan orang-orang kreatif. Dalam hal menyatukan orang kreatif ini diwujudkan dengan adanya pertemuan antar orang-orang kreatif, menyediakan ruang, menyediakan dukungan infrastruktur/jaringan, dukungan pengembangan usaha, dan dukungan pelibatan orang-orang kreatif. 
Coworking space mulai tumbuh dan berkembang di wilayah perkotaan dimulai pada tahun 2007/2008 seiring dengan adanya fenomena krisis ekonomi dunia. Coworking space merupakan sebuah ruang fisik yag dibangun untuk mengakomodasi individu atau kelompok orang yang bergerak di bidang entrepreneur untuk bertemu, berkolaborasi, berdiskusi, berbagi pengetahuan atau bekerja untuk menghasilkan suatu produk inovatif (Moriset, 2014). Sejalan dengan pendapat Merkel (2015) yaitu munculnya coworking space ini juga dapat dikaitkan dengan perkembangan peneraan konsep kota kreatif di mana keberadaan orang kreatif sebagai sumber daya utama dalam pengembangan kota kreatif. Penelitian ini bermaksud mengkaji nilai-nilai coworking space dari persepsi orang kreatif yang menggunakan coworking space dalam kaitannya dengan penerapan konsep kota kreatif dengan menggunakan studi kasus di Daerah Istimewa Yogyakarta.

\section{METODE PENELITIAN}

Pendekatan penelitian mengenai nilai-nilai coworking space dalam mendukung konsep kota kreatif menggunakan pendekatan kualitatif. Pendekatan ini dipilih dengan alasan untuk menyesuaikan tujuan penelitian ini, yaitu untuk mengkaji nilai - nilai coworking space dari persepsi pengguna yang kemudian dikaitkan dengan konsep kota Kreatif dengan menggunakan studi kasus di Daerah Istimewa Yogyakarta. Penelitian ini juga dimaksudkan untuk membangun pengetahuan berdasarkan perspektif konstruktif yang dibangun secara mendalam dari kondisi lapangan, nilai-nilai sosial, dan perspektif partisipatoris pengguna coworking space sebagai narasumber dalam penelitian ini.

Strategi Penelitian ini menggunakan studi kasus untuk menjawab pertanyaan penelitian ini, yaitu: "Bagaimana nilai-nilai coworking space di Daerah Istimewa Yogyakarta dari persepsi pengguna dan bagaimana coworking space dapat berperan dalam penerapan konsep kota kreatif ?". Pada pertanyaan penelitian tersebut, dapat dilihat bahwa penelitian ini bermaksud menjawab bagaimana (how) nilainilai coworking space dari persepsi pengguna, dan mengapa (why) coworking space memberikan pengaruh terhadap konsep kota kreatif.

Sebagaimana umumnya pendekatan penelitian kualitatif, penelitian ini menggunakan metode pengumpulan data dengan cara wawancara, observasi lapangan, dan studi dokumen. Wawancara dilakukan kepada para pengguna coworking space di Yogyakarta. Wawancara diarahkan untuk mendapatkan informasi dari narasumber tentang pengetahuan, pengalaman, dan persepsi mereka tentang hal-hal yang berkaitan dengan kebutuhan data penelitian nilai - nilai coworking space dalam kaitannya dengan konsep kota kreatif di Daerah Istimewa Yogyakarta. Kemudian observasi lapangan dilakukan untuk mengamati gejala yang tampak dari kegiatan dan peran dari keberadaan coworking space di Daerah Istimewa Yogyakarta. Sedangkan studi dokumen dilakukan terhadap dokumendokumen terkait dengan kota kreatif di obyek penelitian.

\section{HASIL DAN PEMBAHASAN}

\subsection{Nilai Coworking Space dari Persepsi Pengguna di Yogyakarta}

Menurut Utami (2017), Coworking Space merupakan sebuah bangunan perkantoran multifungsi yang memadukan fungsi perkantoran dan pusat komunitas yang di dalamnya menawarkan sharing area yang cukup untuk mengakomodasi kegiatan pelaku perkantoran yang khususnya bersifat startup business maupun komunitas. Secara umum coworking space berfungsi dalam hal penyediaan ruang atau tempat kerja bagi orang-orang yang memiliki latar belakang yang berbeda-beda yang biasanya orang-orang tersebut menggunakan pikiran dan kreativitas mereka. Orang-orang dengan latar belakang tersebut dapat dikategorikan sebagai orang kreatif (Florida, 2005). Daerah Istimewa Yogyakarta sebagai kota pelajar, menjadikan kota ini mulai berkembang dan bermunculan pengusaha pemula dan pekerja paruh waktu berbasis digital dan networking. Daerah Istimewa Yogyakarta menjadi tujuan kota bagi para startups dan freelancers yang salah 
satunya didukung oleh keberadaan coworking space untuk tempat mereka bekerja atau melakukan aktivitas lainnya. Dari hasil observasi terhadap beberapa coworking space di Daerah Istimewa Yogyakarta menunjukkan bahwa orang kreatif saat ini sudah mulai memanfaatkan coworking space untuk menunjang aktivitas terkait dengan pekerjaan mereka. Berikut ini adalah hasil analisis peran cowoking space dikaitkan dengan nilai-nilai coworking space dari persepsi pengguna di di Daerah Istimewa Yogyakarta:

\section{1) Nilai Komunitas}

Dari survei yang dilakukan, orang-orang yang menggunakan coworking space membutuhkan space atau ruang untuk tujuan bertemu dengan rekan kerja maupun komunitas mereka untuk berdiskusi dan bertukar pikiran. secara umum pengguna coworking space tersebut pada awalnya mereka membutuhkan tempat tersebut untuk menyelesaikan berbagai kegiatan baik pekerjaan maupun tugas-tugas lainnya, yang kemudian mereka bertemu dengan sesama pengguna coworking space lainnya dan melakukan mereka saling melakukan interaksi. Mereka melakukan interaksi karena mereka memiliki ketertarikan yang sama, kemudian pada akhirnya mereka dapat membentuk komunitas. Beberapa contoh komunitas yang telah dibentuk dari wadah ruang kreatif berupa coworking space di Yogyakarta ini misalnya adalah komunitas startups digital dan komunitas komunitas sociopreneur, dan komunitas yang terkait dengan sektor kreatif.

Proses pembentukan komunitas ini diawali dengan para pengguna coworking space memiliki ketertarikan yang sama, mereka melakukan interaksi, dan berbagi pengetahuan tentang topik yang menjadi ketertarikan bersama yang pada akhirnya mereka dapat membentuk komunitas. Ketertarikan yang sama tersebut, untuk kemudian melalui coworking space dapat menumbuhkan rasa memiliki komunitas yang kuat dan pada akhirnya dari komunitas tersebut mereka menindaklanjuti dengan berbagai inovasi dan kegiatan yang dikembangkan untuk komunitas mereka.
Coworking space memiliki peran dalam hal pembentukan dan pengembangan komunitas. Dalam hal pembentukan komunitas ini, coworking space sebagai wadah atau tempat untuk bertemu baik melakukan kegiatan rapat atau menyelesaikan progres pekerjaan. Dengan adanya pertemuan antar pengguna coworking space atau dalam lingkup kota kreatif dapat disebut sebagai orang-orang kreati dapat memunculkan interaksi antar orang-orang tersebut yang pada akhirnya berpeluang dalam membentuk suatu komunitas yang kuat dan memberi rasa memiliki komunitas tersebut. Peran coworking space dalam hal pembentukan komunitas ini juga didukung oleh pendapat dari Indi Hall dalam Merkel (2015) yaitu coworking space dibangun dengan meletakkan aspek komunitas sebagai daya tarik utama yang kemudian coworking space tersebut juga akan menciptakan komunitas di dalamnya.

\section{2) Nilai Aksesibilitas}

Menurut Stumpf, 2013 (dalam Utami, 2017) Coworking space dibangun dengan berpedoman pada empat aspek yaitu (1) dapat dimanfaatkan dan dijangkau oleh orang-orang baik secara individu maupun kelompok dengan latar belakang yang berbeda-beda, (2) bersifat aksesibel secara keuangan, (3) terbuka untuk semua komunitas, dan (4) mudah dijangkau bagi penyandang cacat. Kasus coworking space di Daerah Istimewa Yogyakata secara umum sudah dibangun dengan mengikuti aspek aksesibilitas tersebut. Sebagian besar Coworking space dibangun dengan mengintegrasikan konsep coffeeshop di Yogyakarta sudah bersifat terbuka untuk umum baik secara individu maupun kelompok, sekaligus terbuka untuk semua komunitas. Namun untuk beberapa coworking space yang dibangun oleh suatu perusahaan tertentu atau yang dikembangkan oleh suatu perguruan tinggi hanya dapat digunakan untuk pengguna yang telah menjadi anggota (member) seperti coworking space di Jogja Digital Valley milik PT. Telkom, Innovative Academy Hub milik Universitas Gadjah Mada, Amikom Bussiness Park milik Universitas Amikom Yogyakarta. 
Nilai aksesibilitas dari coworking space di Daerah Istimewa Yogyakarta hampir semuanya sudah memenuhi aspek aksesibilitas secara keuangan. Hal ini dapat dilihat dari beberapa coworking space dibuat dengan konsep mengintegrasikan dengan coffeeshop yang menyediakan beberapa jenis minuman dan makanan yang secara harga dapat dijangkau oleh pra pengguna coworking space dengan kisaran harga rata-rata untuk satu jenis minuman atau makanan adalah $\mathrm{Rp} 15.000$, Rp 50.000,- rupiah. Harga tersebut cukup dapat dijangkau bagi pengguna coworking space di Yogyakarta yang sebagian dari mereka adalah mahasiswa, pekerja freelance, dan pengusaha pemula. Namun untuk aspek aksesibel bagi para penyandang cacat belum sepenuhnya dapat terpenuhi. Sebagian besar coworking space belum mempertimbangkan bagaimana para penyandang cacat dapat memanfaatkan fasilitas coworking space secara maksimal. Hal ini dapat dilihat dari desain bangunan eksterior dan interior yang belum ada yang secara khusus diperuntukkan dan mudah dijangkau oleh para penyandang cacat secara mandiri.

\section{3) Nilai Kolaborasi}

Coworking space memiliki peran sebagai wadah bertemunya para individu atau kelompok orang yang dalam hal ini sebagian besar dari mereka di Daerah Istimewa Yogyakarta adalah para freelancer, mahasiswa, dan entrepreneur. Koneksi dengan orang lain menjadi alasan mengapa orang kreatif mau membayar untuk bekerja di coworking space yang berlawanan dengan bekerja dari rumah atau kantor lainnya yang sifatnya gratis. Para freelancer dan enterpreneur dari latar belakang yang berbedabeda, mereka melakukan interaksi dan berbagi pengetahuan yang dapat mendorong untuk menciptakan peluang kolaborasi dalam hal penciptaan produk-produk yang memiliki nilai secara ekonomi atau produk kreatif. Keberadaan coworking space berperan dalam mewadahi kegiatan kolaborasi tersebut, yaitu sebagai tempat melakukan diskusi, rapat, dan menyelesaikan pekerjaan. Di sisi lain coworkers dapat menemukan orang-orang dengan latar belakang keahlian yang bervariasi dan terspesialisasi yang diantaranya adalah desain web, marketing communication, business development, public relation, dan lain-lain di dalam wadah coworking space yang memiliki peluang untuk melakukan kolaborasi.

Beberapa coworking space di Daerah Istimewa Yogyakarta terutama yang dikelola oleh suatu perusahaan dan perguruan tinggi memungkinkan para pengguna untuk dapat bekerja sama dalam hal menghasilkan layanan baru atau bisnis baru serta mendorong kemitraan profesional antar coworkers. Hal ini juga sesuai dengan pendapat Stumpf, 2013 (dalam Utami, 2017) menyatakan bahwa nilai inti dari kolaborasi yang diwadahi oleh coworking space adalah individu yang bersedia untuk bekerja dengan pekerja lain. Nilai kolaborasi dalam coworking space tidak hanya berarti bekerja sama saja tetapi juga memiliki makna untuk membagikan pengalaman dan pengetahuan mereka yang berpeluang dalam penciptaan kolaborasi antar pengguna coworking space.

\section{4) Nilai Komunikasi}

Sebagai coworking space, di mana merupakan sebuah ruang fisik yang di dalamnya memiliki fasilitas untuk mempertemukan orang-orang atau komunitas. Hal ini dapat juga dimaknai bahwa di dalam coworking space akan terjadi komunikasi dan interaksi antar pengguna. Sosialisasi orang di dalam coworking space sifatnya tidak diwajibkan atau dipaksakan, karena setiap orang dalam wadah coworking space dapat memilih kapan dan bagaimana mereka akan berinteraksi dengan orang lain. Ketika coworking space sudah mulai berkembang dan menjadi lebih umum sebagai suatu wadah praktik sosial diantara para pekerja freelance di berbagai kota besar termasuk di Daerah Istimewa Yogyakarta, kemudian praktik sosial tersebut secara langsung maupun tidak langsung akan menciptakan komunikasi para pekerja freelance tersebut.

Nilai komunikasi ini juga diperkuat oleh Stumpf, 2013 (dalam Utami, 2017) bahwa coworking space juga memiliki manfaat yang 
dirasakan melalui komunikasi dan kesediaan berbagi pengetahuan dan belajar dari orang lain. Peran coworking space di Daerah Istimewa Yogyakarta dalam menciptakan komunikasi ini juga terlihat dari adanya kolaborasi diantara para pengguna coworking space, terutama bagi mereka yang menggunakan coworking space secara berkelompok. orang-orang yang menggunakan coworking space secara berkelompok diikuti dengan kegiatan diskusi membahas hal-hal yang sedang menjadi kegiatan atau pekerjaan yang harus dikerjakan untuk diselesaikan. Aktivitas diskusi di coworking space ini juga dapat dimaknai bahwa mereka melalukan praktik sosial dalam hal menciptakan komunikasi melalui wadah coworking space.

\section{5) Nilai Kreativitas}

Kreativitas berhubungan dengan kegiatankegiatan atau kemampuan dalam hal menghasilkan sesuatu yang bersifat baru atau mengandung kebaruan. Konsep kreativitas tidak dapat lepas dari kemampuan untuk menghasilkan sesuatu yang baru (Howkins, 2001). Dalam hal ini, kreativitas diartikan sebagai proses untuk menghasilkan ide-ide yang kemudian ditransformasikan melalui inovasi menjadi sesuatu yang memiliki nilai. Kaitan nilai coworking space dengan kreativitas yang terjadi di Daerah Istimewa Yogyakarta adalah suasana yang tercipta dari coworking space ini mampu mendorong munculnya ide-ide kreatif yang dihasilkan oleh para pengguna coworking space.

Bekerja di coworking space kemungkinan besar dikelilingi oleh banyak orang-orang kreatif dari latar belakang yang berbeda-beda. Hal ini bagi sebagian para pengguna coworking space juga merupakan salah satu alasan mereka untuk menggunakan coworking space karena dengan dikelilingi oleh orangorang kreatif dapat memberikan pengaruh dan akan mendorong pengguna untuk dapat lebih produktif, kreatif, dan memungkinkan bagi mereka untuk sharing dan kolaborasi.

Selain dari sisi pekerjaan yang harus diselesaiakan, orang - orang kreatif yang menggunakan coworking space sebagai tempat kerja bagi mereka cenderung melihat pekerjaan mereka menjadi lebih bermakna. Orang kreatif yang menggunakan coworking space di Daerah Istimewa Yogyakarta ini melaporkan bahwa mereka menemukan makna yang dapat membawa diri mereka untuk bekerja dengan sepenuh hati, percaya diri, dan membuat identitas kerja seseorang lebih kuat. Keragaman orang-orang kreatif yang bekerja di coworking space karena masing-masing orang mempunyai keahlian yang berbeda-beda sehingga mereka dapat berpeluang untuk saling memberikan bantuan. Pengguna coworking space di Daerah Istimewa Yogyakarta menyatakan bahwa dengan menggunakan coworking space dapat mendorong dan memunculkan ide-ide kreatif. Hal ini didukung dengan suasana coworking space dengan fasilitas yang nyaman seperti meja dan kursi kerja, internet dengan kecepatan tinggi, dan cafebar. Kemudian mereka juga menyatakan bahwa alasan menggunakan coworking space adalah mereka merasakan kenyamanan untuk bekerja dengan ruang kerja yang kondusif dapat memudahkan untuk memunculkan ide-ide kreatif atau gagasan-gagasan baru yang pada akhirnya dapat meningkatkan produktivitas kerja.

\subsection{Diskusi Nilai - Nilai Coworking Space dalam Kaitannya dengan Konsep Kota Kreatif di Daerah Istimewa Yogyakarta}

Seiring dengan perkembangan waktu, Daerah Istimewa Yogyakarta sebagai kota yang dihuni oleh banyak anak muda kreatif juga berkembang pula pusat - pusat kreatif. Coworking space di kota ini sebagai suatu respon terhadap perubahan kebiasaan kerja bagi sebagian para pekerja freelance dan pelaku usaha pemula yang mencari dan membutuhkan ruang kerja yang lebih profesional. Model ruang coworking space di Kota Yogyakarta sebagian besar sudah menyediakan lingkungan yang mendukung bagi para pengguna untuk memfasilitasi dalam hal penyediaan ruang kerja. Namun, pada kenyataannya selain dapat mewadahi sebagai tempat kerja, coworking space di Daerah Istimewa Yogyakarta juga tidak hanya ditujukan untuk pekerja freelance dan 
pengusaha pemula saja, namun coworking space juga dapat menghubungkan orang-orang kreatif dari berbagai sektor dan latar belakang keahlian yang berbeda-beda untuk membentuk komunitas dan berkolaborasi. Konsep coworking space di Yogyakarta tidak hanya sebagai ruang untuk bekerja, namun untuk jenis coworking space yang dikembangkan oleh suatu perusahaan teknologi dan perguruan tinggi juga melaksanakan kegiatan seperti workshop, sharing, talk show untuk pengembangan kreativitas, pengetahuan, dan keahlian yang pada akhirnya memungkinkan untuk menciptakan komunitas, kolaborasi, dan terhubung untuk menciptakan produk yang bernilai secara ekonomi dan bahkan dapat mencipatakan alternatif solusi atas permasalahan kota.

Menurut Landry (1995), kota sebagai tempat bagi penduduk untuk menjalankan aktivitas kehidupan sehari-hari dalam rangka memenuhi kebutuhan mereka dan tempat untuk dapat mengembangkan mimpi, ide, aspirasi, dan ide mereka. Saat ini, sebagian kehidupan kerja di kawasan perkotaan sudah mulai bertransformasi dari pekerjaan yang dilakukan di kantor tradisional beralih dengan memanfaatkan coworking space. Coworking space dianggap sebagai 'serendipity accelerators' yang dirancang untuk menampung orang-orang kreatif dan para entrepreneur untuk menemukan suatu solusi atas permasalahan dan mengembangkan ideide kreatif dengan dukungan nilai-nilai coworking space sebagai bagian dari penerapan konsep kota kreatif. Coworking space mengandung nilai - nilai yang mampu mendorong penciptaan kreativitas dan inovasi yang kemudian ditransformasikan ke dalam produk kreatif merupakan bagian dari konsep pengembangan kota kreatif.

Lebih lanjut lagi, menurut Landry (2006), sebuah kota kreatif dibangun setidaknya berdasarkan tiga aspek penting yaitu (1) memelihara dan mengembangkan potensi ekonomi kreatif, (2) memelihara kelas kreatif, yaitu golongan atau individu kreatif, dan (3) merencanakan dan mengembangkan creative mileu (lingkungan kreatif). Tiga aspek ini memiliki peranan yang penting yang mencakup aspek ekonomi, sosial, dan lingkungan. Coworking space sebagai salah satu ruang kreatif dikaitkan dengan konsep kota kreatif yaitu memiliki fungsi sebagai lingkungan kreatif yang bersifat fisik dan mampu mewadahi golongan kelas kreatif dalam penerapan kota kreatif. Keberadaan dan perkembangan coworking space dalam lingkup ekonomi kota juga mampu dapat dikaitkan dengan perkembangan ekonomi kota yaitu sektor ekonomi kreatif dan ekonomi digital. Dua sektor ekonomi ini juga berkaitan erat dengan pengembangan kota kreatif dan mendorong perubahan yang cukup besar dalam hal kebutuhan ruang - ruang kreatif yang diperuntukkan untuk menghasilkan produk-produk kreatif. Hal ini sejalan dengan fenomena munculnya coworking space yang umumnya juga berkembang di pusat kota yang merupakan tempat konsentrasi penduduk terutama para pekerja di sektor kreatif, pekerja freelance, dan para entrepreneurs berada.

Coworking space sebagai bagian dari pengembangan ekonomi kreatif dan ekonomi digital mendorong munculnya produk kreatif yang dihasilkan oleh orang kreatif atau dalam istilah yang disampaikan oleh Florida (2005) disebut sebagai kelas kreatif, kemudian pada akhirnya produk kreatif yang dihasilkan tersebut adalah suatu barang atau jasa yang memiliki nilai. Di sisi lain, kebutuhan akan coworking space juga mendorong terjadinya transformasi akan konsumsi ruang pada suatu wilayah untuk mewadahi para pekerja kreatif dalam rangka menghasilkan karya-karya kreatif (Moriset, 2014). Menurut Moriset (2014), fenomena global mengenai perkembangan coworking space, dimana keberadaan coworking space tersebut masih bersifat terpusat pada kawasan dapat disebut sebagai kawasan kota kreatif dimana pada distrik tersebut juga dapat menumbuhkan peningkatan ekonomi secara signifikan.

Fenomena berkembangnya coworking space di Daerah Istimewa Yogyakarta yang juga merupakan bagian dari fenomena global ditandai dengan keberadaan orang-orang kreatif yang menyebar di seluruh bagian kota Yogyakarta yang kemudian memunculkan kebutuhan akan pusat-pusat ruang kerja 
dengan konsep coworking space. Jika dilihat dari keberadaan lokasi coworking space di Daerah Istimewa Yogyakarta secara menyeluruh dalam lingkup ruang wilayah terlihat bahwa terjadi konsentrasi di kawasan dengan karakter perkotaan terutama di area yang dekat dengan pusat pendidikan perguruan tinggi. Konsentrasi titik-titik keberadaaan coworking space ini yang pada akhirnya dapat dimaknai bahwa secara langsung membutuhkan alokasi ruang kota. Konsentrasi coworking space di Daerah Istimewa Yogyakarta yang berlokasi di kawasan perkotaan pada akhirnya terbentuk kawasan baru dengan karakter kawasan kreatif yang menghasilkan produk-produk kreatif yang bernilai secara ekonomis. Diskusi nili-nilai coworking space dalam kontek kota kreatif dideskpsikan pada tabel 1.

\section{Tabel 1 Nilai - Nilai Coworking dalam Konteks Kota Kreatif di D.I. Yogyakarta}

\section{No. Konsep kota kreatif $\quad$ Nilai - Nilai Coworking dalam Konteks Kota Kreatif di D.I. Yogyakarta}

1. Kota sebagai tempat bagi penduduk untuk menjalankan aktivitas kehidupan seharihari dalam rangka memenuhi kebutuhan mereka dan tempat untuk dapat mengembangkan mimpi, ide, aspirasi, dan ide mereka (Landry, 1995) a. Coworking space di D.I. Yogyakarta sebagai suatu respon terhadap perubahan kebiasaan kerja bagi sebagian para pekerja freelance dan pelaku usaha pemula yang mencari dan membutuhkan ruang kerja yang lebih profesional.

b. Coworking space di D.I. Yogyakarta sebagai 'serendipity accelerators' yang berperan untuk menampung orang-orang kreatif dan para entrepreneur dalam menemukan suatu solusi atas permasalahan dan mengembangkan ide-ide kreatif dengan dukungan nilai-nilai coworking space yaitu nilai komunitas, nilai aksesibilitas, nilai kolaborasi, nilai komunikasi, dan nilai kreativitas.
2. Orang-orang yang berkumpul dan terhubung akan mendorong pertumbuhan ekonomi kota (Florida, 2002). Kemudian munculnya produk kreatif yang dihasilkan oleh orang kreatif atau dalam istilah yang disebut sebagai kelas kreatif (Florida, 2005). a. Fenomena munculnya coworking space di D.I. Yogyakarta berkembang di pusat kota yang merupakan tempat konsentrasi penduduk terutama para pekerja di sektor kreatif, pekerja freelance, dan para entrepreneurs yang merupakan kelar kreatif karena selalu menggunakan ide-ide mereka.

b. Coworking space di D.I. Yogyakarta mengandung nilai - nilai yang mampu mendorong penciptaan kreativitas dan inovasi yang kemudian ditransformasikan ke dalam produk kreatif yang salah satunya adalah produk startup digital.

c. Keberadaan dan perkembangan coworking space dalam lingkup ekonomi kota dapat dikaitkan dengan perkembangan ekonomi kota yaitu sektor ekonomi kreatif dan ekonomi digital untuk menghasilkan produk-produk kreatif. produk kreatif yang dihasilkan tersebut adalah suatu barang atau jasa yang memiliki nilai secara ekonomi Kota kreatif dibangun
berdasarkan tiga aspek penting yaitu (1) memelihara dan mengembangkan potensi ekonomi kreatif, memelihara kelas kreatif, yaitu golongan atau individu kreatif, dan (3) merencanakan dan mengembangkan lingkungan kreatif atau a. Coworking space di D.I. Yogyakarta sebagai salah satu ruang kreatif yang memiliki fungsi sebagai lingkungan kreatif yang bersifat fisik dan mampu mewadahi golongan kelas kreatif yang berkumpul bersama untuk saling berlajar dan berbagi pengetahuan satu sama lain.

b. Coworking space di D.I. Yogyakarta tidak hanya ditujukan untuk pekerja freelance dan pengusaha pemula saja, namun coworking space juga dapat menghubungkan orang-orang kreatif dari berbagai sektor dan latar belakang keahlian yang berbeda-beda 


\begin{tabular}{lll}
\hline No. & Konsep kota kreatif & Nilai - Nilai Coworking dalam Konteks Kota Kreatif di D.I. \\
Yogyakarta
\end{tabular}

Sumber:Hasil Analisis, 2020.

\section{KESIMPULAN}

Daerah Istimewa Yogyakarta sebagai kota pendidikan dan pusat budaya mampu menjadikan kota ini sebagai tempat berkembangnya sektor-sektor kreatif dengan sumber daya utama adalah orang-orang kreatif. Karakter yang dimiliki oleh kota ini mampu mencerminkan perkembangan dalam penerapan kota kreatif yang salah satunya ditandai dengan keberadaan coworking space atau ruang kerja bersama sebagai wadah untuk menumbuhkan kembangkan kreativitas dan inovasi, serta sebagai salah satu lingkungan kreatif yang merupakan salah satu indikator kota kreatif. Nilai-nilai coworking space di Daerah Istimewa Yogyakarta sebagai lingkungan kerja di sektor kreatif mampu mendorong munculnya komunitas, kolaborasi, komunikasi, dan kreativitas dapat berkontribusi dalam menghasilkan inovasi dan penciptaan peluang nilai ekonomi. Keberadaan coworking space di kota ini juga memiliki peranan yang signifikan dalam hal menghasilkan orang-orang kreatif atau pekerja kreatif (creative class) sebagai sumber daya utama dalam pengembangan kota kreatif.

\section{UCAPAN TERIMAKASIH}

Terimakasih kepada Direktorat Lembaga Penelitian Universitas Amikom Yogyakarta, Ketua Program Studi Perencanaan Wilayah dan Kota Universitas Amikom Yogyakarta, Narasumber Pengguna Coworking Space, dan para anggota Startup Digital di Innovative Academy Hub.

\section{REFERENSI}

Bekraf. (2017). "10 Kota Kreatif di Indonesia".http://indonesiakreatif.bekr af.go.id/iknews/10- kota-kreatif-diindonesia-2/ . diakses pada Juli 2018.

British council. 2017 Enabling Space: Mapping Creative Hubs in Indonesia. Jakarta: Centre for Innovation Policy and Governance.

Florida, R. L. 2005. Cities and The Creative Class. New York: Routledge. Howkins, J. 2001. The Creative Economy: How People Make Money From Idea. United Kingdom: The Penguin Press.

Jamal, Audrey C. 2018. Coworking space in mid-sized cities: A partner in downtown economic development. Dalam sage journal, "Environment and Planning A: Economy and Space", volume 50(4) 773-788.

Landry, C. dan Bianchini, F. 1995. The Creative City. Bournes Green:

Comedia.

Landry, C. 2006. The Art of City-Making. London: Earthscan.

Merkel, Janet. 2015. Coworking in The City. Dalam Ephemera Journal volume 15(1): 121-139. London.

Moriset, Bruno. 2014. "Building New Places of The Creative Economy. The Rise of Coworking Spaces". Dalam $2^{\text {nd }}$ Geography on Innovation International 
Conference. Utrecht University:

London.

Rachman, Fadhly Fauzi. 2018.

"Sumbangan Ekonomi Kreatif ke PDB RI Naik Rp 70 Triliun/Tahun" dalam Detik Finance https://finance.detik.com/beritaekonomi-bisnis/d3888781/sumbangan-ekonomi-kreatif- ke-pdb-ri-naik-rp-70-triliuntahun. Diakses pada tanggal 22 Juli 2020.

Utami, Valentina Kris. 2017. "Coworking Space di Kota Yogyakarta, dengan Menggunakan Metode Psikologi Lingkungan untuk Menciptakan Suasana Bahagia". Dalam http://ejournal.uajy.ac.id/id/eprint/12879. Diakses pada Desember, 2018. 